\title{
The Implementation of the NHT Type of Cooperative Learning Model to Improve Student's Activities and Learning Achievement in Basic Techniques for Passing Inner Legs
}

\section{Ida Bagus Widana Siswaya ${ }^{*}$}

SMKN 2 Singaraja

\section{A R T I C L E I N F O}

Article history:

Received 19 November

2018

Received in revised form

30 December 2018

Accepted 10 January 2019

Available online 20

February 2019

Keywords:

learning activities,

learning outcomes of the

basic inner foot passing

technique, NHT Type

Cooperative Learning

model

\begin{abstract}
A B S T R A C T
The purpose of this research was to find out the increase in activity and learning outcomes of basic inner foot passing techniques in students of class X P 2 Singaraja State Vocational High School 2 2018/2019 after the implementation of the NHT Type Cooperative Learning Model. This research is a classroom action research. The subjects in this class action research were students of class $X P 2$ of Singaraja State Vocational High School 2 of 2018/2019 in 36 people. While the object is activity and the results of learning basic techniques of passing the inner leg. Data on student learning activities are collected by observation sheet, while data on learning outcomes of basic techniques of passing the inner leg are collected by performance tests. Data analysis used in this study used descriptive data analysis. Based on the data analysis carried out it can be concluded that: 1) learning activities of the basic techniques of passing the inner leg increased through the implementation of the NHT type cooperative learning model for students of class XP 2 Singaraja State Vocational High School 2018/2019, and 2) the results of learning basic passing techniques inner leg increases through the implementation of the NHT type cooperative learning model in class XP 2 Singaraja State Vocational High School 2018/2019.
\end{abstract}




\section{Introduction}

The curriculum continues to be adjusted, various approaches and methods of learning are perfected, additional learning of extra hours continues to be carried out, but the results of learning physical education, sports and health (PJOK) are not in line with expectations. One reason is the implementation of learning PJOK subjects often experience problems. For students, the problem is often experienced because most students already assume that PJOK is a lesson that requires great energy, needs sufficient body strength and requires special skills besides that most students at every level of education still think that the PJOK is a difficult subject and often causes learning problems. Even though various integrated efforts have been made by the government and those who care about education in order to improve the quality of education, all these efforts have not produced optimal results. Learning planning that is made and which will be presented in the class is still less directed at efforts to improve PJOK student activities and learning outcomes.

In PJOK lessons, especially in Vocational School, students tend to be less active in participating in the learning process, this is evident from the activities and learning outcomes obtained by students that are unsatisfactory or do not meet the objectives indicated by the mastery of the motion techniques taught. Students tend to underestimate PJOK students, because they concentrate more on the subjects tested on the national exam.

Based on the results of preliminary observations conducted by researchers on Wednesday, August 29 in class XP 2 of Singaraja State Vocational High School 2 2018/2019, learning activities were 36 students (18 female and 18 male) on basic passing soccer technique material the inner foot ball obtained during observation is quite active. Can be seen from the components of learning activities of students consisting of visual, verbal, listening, metric, mental and emotional activities. Based on the observations of the six components of the activity the percentage results are obtained as follows:

There are no students in the very active category $(0 \%), 14$ people $(38.9 \%)$ are in the active activity level category, 17 people $(47.2 \%)$ are in the fairly active activity level category, 5 people $(13.9 \%)$ are in the category of activity levels that are less active, and no people $(0 \%)$ are in the category of activity levels that are very less active, with a percentage of completeness of 14 people (38.9\%) active and 22 people $(61.1 \%)$ not yet active. Based on the data above, the researcher can find out the classical average of learning activities in the basic technique of passing the inner leg of 5.8 which is classified as quite active. So that it can be known how many students are complete and students are not complete.

When viewed from the results of observations, the completeness of learning outcomes for the knowledge aspect, students who are in the excellent category do not exist $(0 \%), 16$ good categories (44.4\%), and 20 people (55.6\%), and there are no students in the less category $(0 \%)$. So the number of students who complete the Basic Techniques of Inner Passing Foot aspects of classical knowledge are 16 people (44.4\%) and 20 people have not finished (55.6\%), with a percentage of the average value of learning outcomes in a classical manner, $78.8 \%$ in the unfinished category. By analyzing the knowledge competency learning outcomes data of students as a whole it seems that it has not met the target, because it has not met the minimum completeness criteria (KKM) of schools for PJOK subjects of 70 classical completeness. The problem that arises in the aspect of knowledge is the lack of understanding of students about the basic techniques of passing the inner leg, this is due to the lack of attention of students when the teacher explains and learning is still the dominant teacher who is more active

Mastery of learning outcomes for aspects of skills, students who are in the excellent category do not exist (0\%), good categories as many as 17 people (47.2\%), quite good as many as 19 people $(52.8 \%)$ and not good there $(0 \%)$. So the number of students who complete the basic technique of passing legs part in the skills aspect in a classical manner is 17 people (47.2\%) and 19 people (52.8\%) are incomplete, with a percentage of the average learning outcomes in classics, $79.5 \%$ who are in the unfinished category. By analyzing the learning outcomes of competency learning skills of the students as a whole, the results of skills competency learning have not met the target, because they do not meet the KKM standards for schools for PJOK subjects of 70 classical completeness.

Mastery of learning outcomes for aspects of attitude, students who are in the excellent category do not exist $(0 \%)$, good categories as many as 36 people $(100 \%)$, quite good categories and lacking none $(0 \%)$. So the number of students who complete the basic technique of passing legs part in the attitude aspect classically is 36 people $(100 \%)$ complete and no students who do not complete $(0 \%)$, with the percentage value of the average learning outcomes in a classic, $83.6 \%$ are in the complete category. By analyzing the competency learning outcomes data of the students' attitudes as a whole it seems that they have fulfilled completeness, because they have met the KKM standards for schools for PJOK subjects of 70 classical completeness. So the existence of students who have problems with learning outcomes is caused by (1) in terms of cooperation, students are still lacking to collaborate in learning and tend to be 
individual, (2) in terms of discipline, there are still many students who dress less neatly, late when coming and doing activities outside the material during learning, (3) in terms of responsibility, students are less responsible in using learning tools.

So when viewed from the average activity and learning outcomes of the basic techniques of passing legs in the above section it can be concluded that, the activities and results of learning the basic techniques of passing the inner leg in class X P 2 of SMK N 2 Singarajaare not complete the limit of study. This is due to the implementation of learning models that have not been effective on the material presented. The learning model that is implemented has not involved or stimulated students to be more active and creative during the learning process. Based on the above problems, the researchers tried to provide an alternative problem solving namely by applying the cooperative learning model Numbered Head Together (NHT) in PJOK learning on basic engineering material passing the inner leg. The interest of the researcher applied the NHT type of cooperative learning model because (1) the cooperative learning model with type NHT was a simple learning model, so this cooperative learning model was suitable to be applied to students of XP 2 Singaraja State Vocational School who had never teach by using NHT cooperative learning, 2) in this learning model more students have group discussion opportunities, each student gives their participation maximally and each student has individual responsibility to master the material as well as possible, (3) cooperative learning model with NHT type invites students to learn actively and courageously in expressing opinions in group discussions (Salama, 2018). If there is a concept that has not yet been understood and understood, students can fill each other with other students, exchange ideas so that the concept of students is expected to be truly well understood. The learning atmosphere will be more conducive, which ultimately affects the activities and learning outcomes.

The selection of the NHT learning model was also strengthened by the results of research from previous researchers including (1) Research conducted by Sanjaya, IPEY (2013: 123) in his thesis which concluded the motivation and learning outcomes of the hanging style long jump technique increased through the application of learning models cooperative type NHT on class X.5 students of State 1 Senior High School in academic year 2012/2013, (2) Research conducted by Bawa, IML (2012: 116) in his thesis which concludes activity and results of learning basic techniques of passing football increased through the application of the NHT type cooperative learning model to class XA1 students of SMK Negeri 2 Singaraja in academic year 2011/2012, (3) Research conducted by Tirtawati, NW (2013: 103) in his thesis which concludes motivation and learning outcomes of long jump hanging style increases through the application of the NHT type cooperative learning model to students of class XI IPA 3 of SMA 2 Bangli academic year $2012 / 2013$.

Based on the description above, the researcher intends to conduct research with the title "Implementation of Cooperative Learning Type NHT Model to Improve Activity and Learning Outcomes of Basic Techniques of Inner Passing in Class X P 2 SMK N 2 SingarajaAcademic Year 2018/2019".

\section{Method}

Classroom action research (CAR) is conducted in two cycles with each cycle consisting of two meetings. In each meeting consists of giving material that is repetitive and stabilizing and evaluating learning outcomes.

The design of each cycle consists of four stages, namely: (a) action plan, (b) implementation of action, (c) observation or evaluation, and (d) reflection. The Draft Stage of Classroom Action Research can be described as follows: 


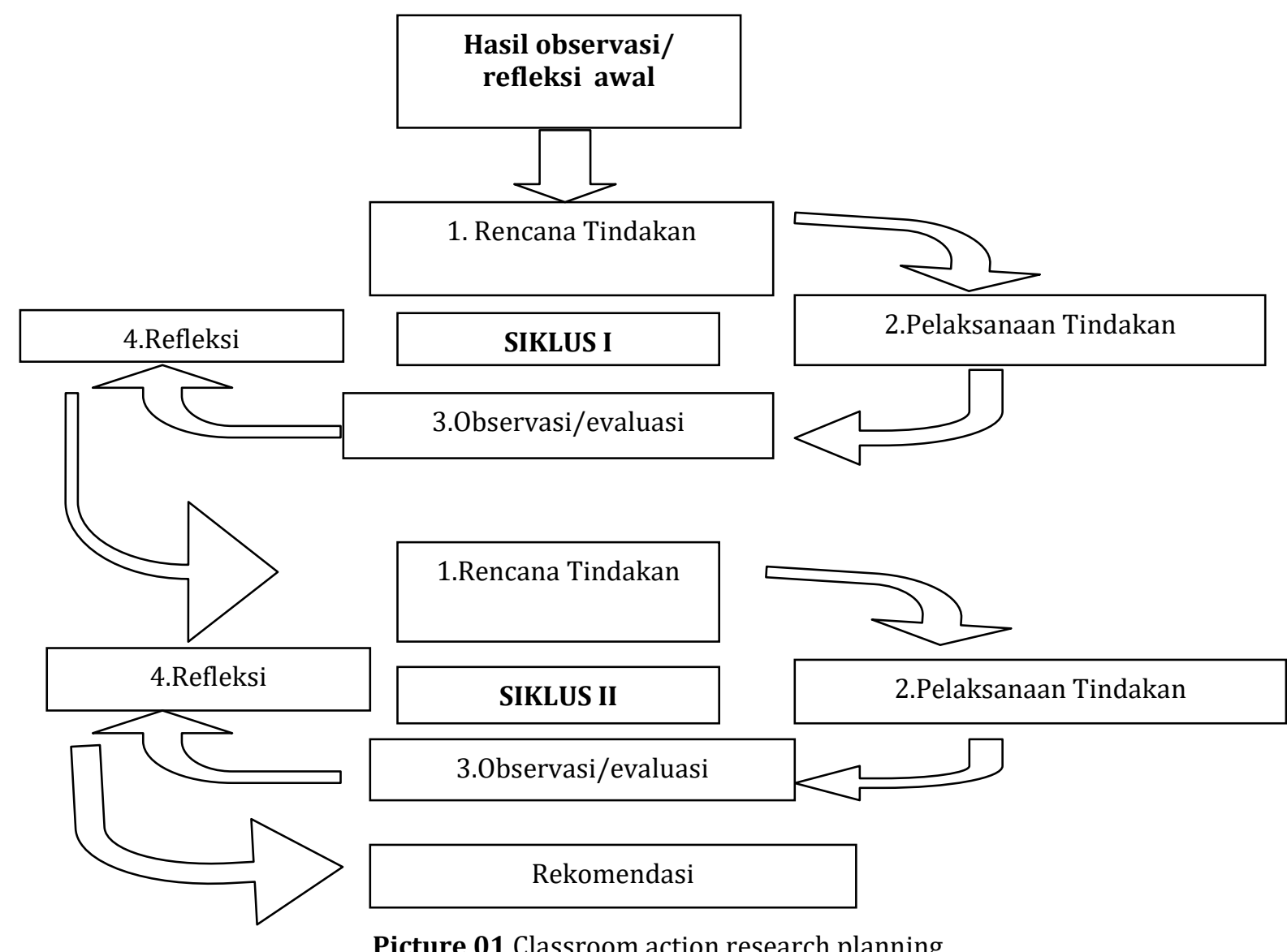

(Sumber : Kanca, 2006: 129)

$$
\text { Caption: }
$$

1. Action Planning

2. Implementation of Action

3. Observation / Evaluation

4. Reflection

This research was conducted on students of class X P 2 Singaraja 2 State Vocational High School 2018/2019 in learning basic techniques in the inner leg Passing carried out in the garden field of the city of Singaraja consisting of 2 cycles where each cycle consisted of 2 meetings.

The subjects of this study were students of class X P 2 Singaraja State Vocational High School 2 of 2018/2019 in 36 people (18 boys and 18 girls).

In obtaining data that is in accordance with the objectives of the researcher, the instruments used are observation sheets of learning activities of students and performance tests of basic techniques of passing the inner leg. The learning activity observation sheet is used to measure the level of activity of students during the learning process. While the performance test is used to measure the mastery of things related to the basic skill of passing techniques of the inner leg. Data on student learning outcomes is carried out using an instrument in the form of assessment.

In this study, the analysis of the data used is in accordance with the formulation of the problem and the research hypothesis. The analysis used in this study is the analysis of activities and results of learning basic passing foot techniques in using Descriptive Statistics analysis.

The completeness criteria of class action research are said to be successful if the activities and learning outcomes are at least in the category of reference guideline assessment (PAP), both individually and classically.

The conversion of the class XP 2 of SMK Negeri 2 Singaraja Academic Year 2018/2019 PJOK subjects are presented in Table 1. 
Table 1. Subject Value Conversion PJOK Class X Vocational School

\begin{tabular}{|c|c|c|c|c|c|}
\hline \multirow{3}{*}{ KKM } & \multicolumn{5}{|c|}{ Kompetensi Penilaian Sikap, Pengetahuan dan Keterampilan } \\
\hline & Rentang & andar & Kriteria (K & Predikat (P) & Keterangan (Ket) \\
\hline & Nasional & Sekolah & & & \\
\hline \multirow{4}{*}{70} & $86-100$ & $91-100$ & Sangat Baik & A & \multirow{4}{*}{$\begin{array}{c}\text { Tuntas (T) } \\
\text { Belum Tuntas (BT) }\end{array}$} \\
\hline & $70-85$ & $80-90$ & Baik & B & \\
\hline & $56-69$ & $70-79$ & Cukup & $\mathrm{C}$ & \\
\hline & $0-55$ & $0-69$ & Kurang & $\mathrm{D}$ & \\
\hline
\end{tabular}

\section{Results and Discussion}

This research was conducted from Saturday, August 18, 2018 to Saturday, September 15 2018, which was held every time at 5:30 a.m. to 7:15 a.m., held at the Singaraja City Park field, with the research subjects being students of XP 2 SMK N 2Academic Year 2018 / 2019 which amounted to 36 people consisting of 18 boys and 18 girls . This study was conducted in two cycles, each cycle with two meetings. The first cycle of the first meeting was held on Wednesday, August 29, 2018 to retrieve data on student learning activities and the second meeting was held on Saturday, September 1, 2018 to collect data on students' activities and learning outcomes.

Whereas the second cycle of the first meeting was held on Wednesday, September 12, 2018 for data collection on student learning activities and the second meeting was held on Saturday, September 15, 2018 to collect data on student activities and learning outcomes, which took place in the Singaraja City Park field, retrieval of activity data and learning outcomes of students involving an Observer, that is the teacher of PJOK at SMK Negeri 2 Singaraja.

Based on the results of data analysis from the implementation of the NHT type of cooperative learning model that aims to improve learning activities and results of the basic technique of passing the inner leg, where the results of research on student learning activities in the first cycle towards PJOK learning, especially in basic technical material passing the inner leg classically in the category of being quite active. By paying attention to the activities and results of learning the basic techniques of passing feet in the first part of the cycle, researchers proceed to the second cycle by looking at the problems in cycle I. This is evident from the reflection of the first cycle where there are still problems in implementing the action.

The problems faced in learning in the first cycle are: (1) the students do not listen to the explanation of the researchers about the basic technique of passing the inner leg (2) the students pay less attention to the demonstration demonstrated by researchers about the basic technique of passing the inner leg, (3) students are less interested and eager to move the basic techniques of passing the inner leg, (4) students have not dared to ask questions and express opinions because they are afraid and ashamed to be laughed at if the theme is related to the basic technique of passing the inner leg (5) lack of understanding of students towards the NHT type of cooperative learning model, (6) students lack enthusiasm and earnest in carrying out basic techniques of passing the inner leg, (7) lack of opportunities for students to perform basic technique movements passing the inner leg so that the results not maximal.

Based on the problems faced in the first cycle, then the solution is: (1) for students who are less listening when giving material, the students will be called forward to explain the material that has been given, (2) giving an award in the form of plus for students who are serious when doing basic technique movements passing the inner leg so that the view can be directed forward, (3) giving questions about the material that has been delivered so that students do not hesitate in answering the questions given, (4) implementing the NHT type cooperative learning model for students more clearly by providing sheets of stages of NHT type of cooperative learning, (5) providing motivation so that students become more excited and earnest in participating in learning in cycle II about the basic technique of passing legs, (6) align students 3 bersaf so that students in the back can pay more attention to the material presented, (7) divide students into more groups so that the number of students in one group is less that before, so the opportunity to make movements in each student becomes more often.

Learning in the second cycle was very conducive, students already knew and were able to adapt to the NHT type of cooperative learning model. This can be seen from the aspect of learning activities of students, when the researchers demonstrated the movement no longer just watching but actively asked the explanation of the researchers at each stage of the movement that was demonstrated by the researcher. The average learning activity of the basic technique of passing the inner leg classically is classified as active. While for mastering basic material, passing the inner leg is in a good category. This 
increase can not be separated from the implementation of the NHT type cooperative learning model optimally with learning improvements in accordance with the shortcomings that occurred in the previous cycle.

Based on the description above, this means the level of completeness of the results of learning the basic techniques of passing the inner leg in the second cycle has met the standard of completeness in a classical manner which is equal to 70 in accordance with the KKM in Singaraja 2 Vocational School. The increase in activity and learning outcomes in the second cycle is due to: 1) the use of the NHT type cooperative learning model with group learning already understood by students and 2) researchers make improvements based on the constraints experienced in cycle I.

Although the implementation of the second cycle was declared successful, there were still obstacles faced when implementing the NHT type of cooperative learning model, namely: the limited time of conducting the study so that students lacked time to better understand the stages of the learning model that the researcher applied. With these constraints, the solution that the researcher recommends to the teacher is to further implement the NHT type cooperative learning model in PJOK learning, so that students will increasingly understand the learning structure in the NHT cooperative learning model.

Of the many existing cooperative learning models, one of them is the NHT type cooperative learning model. Where by looking at the activities and learning outcomes of the basic techniques of passing the inner leg found the results that by implementing the cooperative learning model NHT type the activities and learning outcomes of students increased in the basic engineering material passing the inner leg.

The increase in learning activities in the basic techniques of passing the parts in students from cycle I to cycle II is presented in table 2.

Table 2. Data Summary of Learning Activities The basic techniques for passing feet in the Learners From Cycle I to Cycle II.

\begin{tabular}{ccccc}
\hline No & Tahapan & $\begin{array}{c}\text { Aktivitas Belajar } \\
\text { Klasikal }\end{array}$ & $\begin{array}{c}\text { Keaktifan Peserta } \\
\text { Didik (Orang) }\end{array}$ & $\begin{array}{c}\text { Peningkatan Aktivitas } \\
\text { Belajar } \\
\text { Siklus I ke Siklus II }\end{array}$ \\
\hline 1. & Siklus I & 7,15 & $\begin{array}{c}28 \text { orang }(77 \%) \\
\text { Sudah aktif }\end{array}$ & 5 Orang $(13,9 \%)$ \\
2. & Siklus II & 8,00 & $\begin{array}{c}33 \text { orang }(94,43 \%) \\
\text { Sudah aktif }\end{array}$ \\
\hline
\end{tabular}

Based on Table 2, data on the learning activities of basic techniques for passing feet, part of students of class X P 2 of Singaraja State Vocational High School 2, can be said that, students who have been active in the first cycle, 28 people (77\%). Because in the first cycle the activities of students still need to be improved, so that in the second cycle again given action. After being given action in the second cycle, the learning activities of students increased to 33 people (94.43\%) who were active. from cycle I to Cycle II there was an increase of 5 people (13.9\%).

Based on the results of the analysis of skills aspects of learning outcomes data from cycle I to cycle II, a significant increase in learning outcomes was obtained. Improved learning outcomes in skills aspects can be seen in table 3 .

Table 3. Summary of Data on Learning Outcomes The basic techniques for passing legs part in the Skills Aspect of Students in Class X P 2 SMK N Singaraja from Cycle I to Cycle II.

\begin{tabular}{ccccc}
\hline No & Tahapan & $\begin{array}{c}\text { Persentase } \\
\text { Ketuntasan Hasil } \\
\text { Belajar }\end{array}$ & $\begin{array}{c}\text { Ketuntasan Peserta } \\
\text { Didik }\end{array}$ & $\begin{array}{c}\text { Peningkatan Hasil Belajar } \\
\text { Aspek Keterampilan } \\
\text { Siklus I ke Siklus II }\end{array}$ \\
\hline 1. & Siklus I & $\begin{array}{c}29 \text { orang }(80,6 \%) \\
\text { 36 orang }(100 \%)\end{array}$ & $\begin{array}{c}\text { Tuntas } \\
\text { Tuntas }\end{array}$ & 7 Orang $(19,4 \%)$ \\
\hline 2. & Siklus II & ron & \\
\hline
\end{tabular}

Based on table 3, the results of the analysis of learning outcomes aspects of the skills of the basic technique of passing the inner foot in students of class XP 2 SMK N 2 Singaraja can be said that the level of completeness of learning outcomes aspects of students in cycle I were 29 people $(80.6 \%)$ ). Because in the 
first cycle there are still students who have not been completed, and the completeness of students in good categories, then given the action again in the second cycle so that the learning outcomes of students in the aspects of skills more increased again. After being given the action in cycle II the completeness of learning outcomes aspects of the basic technique of passing the part of the legs in the students increased by 7 people $(19.4 \%)$ from the first cycle, so the number of completeness of learning outcomes aspects of students in the second cycle became 36 people (100\%).

Berdasarkan tabel 3, hasil analisis data hasil belajar aspek keterampilan teknik dasar passing kaki bagian dalam pada peserta didik kelas X P 2 SMK Negeri 2 Singaraja dapat disampaikan bahwa, tingkat ketuntasan hasil belajar aspek keterampilan peserta didik pada siklus I sebanyak 29 orang $(80,6 \%)$.Karena pada siklus I masih ada peserta didik yang belum tuntas, dan ketuntasan peserta didik dalam kategori baik, maka diberikan kembali tindakan pada siklus II supaya hasil belajar peserta didik dalam aspek keterampilan lebih meningkat lagi. Setelah diberikan tindakan pada siklus II ketuntasan hasil belajar aspek keterampilan teknik dasar passing kaki bagian dalam peserta didik meningkat sebanyak 7 orang $(19,4 \%)$ dari siklus I, sehingga jumlah ketuntasan hasil belajar aspek keterampilan peserta didik pada siklus II menjadi 36 orang (100\%). From the results of the analysis of the data, it can be seen an increase in the completeness of learning outcomes aspects of skills that occur from cycle I to cycle II as many as 7 people (19.4\%).

Based on the data analysis results described above, that activities and learning outcomes increase due to: 1) Students are more active in following a learning process in interacting with friends so that learning is more active and not one-way, 2) The emergence of cooperation between students and students, teams or friends in their groups can complete the motion tasks given by the teacher, 3) Students have a sense of responsibility so students can do the task well in a learning process within the group, 4) Students observe what is exemplified by the teacher or from other people in a learning process, 5) Students' self-confidence in carrying out the motion tasks given by the teacher.

Based on the research that has been done, as for the limitations in conducting this research, that is: the limited time this research was conducted in 2 cycles, so as not to interfere with the school curriculum that has been made. Based on the results of research that researchers have done and supporting theories of the results of the research described above, it can be concluded that the application of the NHT type of cooperative learning model can improve activities and learning outcomes in basic foot passing techniques in students of class XP 2 SMK N 2 Singaraja Academic Year 2018/2019.

The research that has been carried out is not always going smoothly as expected and planned. Because there are obstacles faced by researchers in carrying out this research. The constraints faced are: (a) the number of supporting tools that are less than the number of study groups that have been planned, (b) the response of students to understand material slowly so that it must be explained repeatedly

\section{Conclusions and Suggestion}

Based on the results of data analysis and discussion above it can be concluded that (1) Activity learning basic techniques of passing the inner leg increases through the implementation of the NHT type cooperative learning model for students of class XP 2 SMK N 2 Singaraja Academic Year 2018/2019, and (2) Results learning basic techniques of passing the inner leg increased through the implementation of the NHT type cooperative learning model for students of class XP 2 SMK N 2 Singaraja Academic Year 2018/2019.

Based on the above conclusions, suggestions can be made, namely (a) PJOK Teachers should implement the NHT cooperative learning model as an alternative learning because it is proven to be able to improve activities and learning outcomes of basic techniques of passing the inner leg in students; (2) For schools, it can be used as a guideline in PJOK learning, especially in basic technique of passing the inner leg to improve activities and learning outcomes; (3) It is expected that students who become the subject of further research pay more attention to and understand the learning given in order to be able to add insight into their specific knowledge in learning basic material learning, passing the inner leg and other learning; (4) Other teachers or researchers are expected to conduct follow-up research by implementing the NHT type of cooperative learning model on other basic competencies, to find out that this learning model can not only be applied to large ball learning (soccer), especially the basic technique of passing legs in.

\section{References}

Adnyani, I Gusti Ayu Nyoman. 2011. Penerapan Model Pembelajaran Kooperatif Tipe NHT (Numbered Heads Together) Bermedia Visual dengan Pemberian Pre Test untuk Meningkatkan Hasil Belajar 
IPS pada Siswa Kelas V Semester II SD No 2 Kalibukbuk Kecamatan Buleleng Kabupaten Buleleng Tahun Pelajaran 2010/2011. Skripsi (tidak diterbitkan). Jurusan Pendidikan Guru Sekolah Dasar, FIP, Undiksha.

Bawa, I Made Lanang. 2012. Implementasi Model Pembelajaran Kooperatif Tipe NHT Untuk Meningkatkan Aktivitas Dan Hasil Belajar Teknik Dasar Passing Sepakbola Pada Siswa Kelas X1 Sma Negeri 1 Sukasada Tahun Pelajaran 2011/2012. Skripsi (tidak diterbitkan). Jurusan Penjaskesrek, Undiksha Singaraja.

Kanca, I.N. 2010. Metodologi Penelitian Pengajaran Pendidikan Jasmani Dan Olahraga. Singaraja: Universitas Pendidikan Ganesha.

Katikasasmi, dkk. 2012. "Penerapan Model Pembelajaran NHT dengan Pendekatan SETS Pada Materi Cahaya Untuk Mengembangkan Kreativitas Siswa". Volume 41, Nomor 2 (hlm. 123-130).

Jayadiningrat, Made Gautama, I. Nyoman Tika, dan Ni Putu Yuliani. "Meningkatkan Kesiapan Dan Hasil Belajar Siswa Pada Pembelajaran Kimia Dengan Pemberian Kuis Di Awal Pembelajaran." Jurnal Pendidikan Kimia Indonesia 1.1 (2017): 7-12.

Muthoharoh, Munifatun, I. Made Kirna, and Gusti ayu Indrawati. "Penerapan Lembar Kerja Peserta Didik (LKPD) Berbasis Multimedia untuk Meningkatkan Motivasi dan Hasil Belajar Kimia." Jurnal Pendidikan Kimia Indonesia 1.1 (2017): 13-22.

Muhajir. 2007. Pendidikan Jasmani Olahraga dan Kesehatan. Jakarta: Erlangga

Paturusi, A. 2012. Manajemen Pendidikan Jasmani Dan Olahraga. Jakarta: Rineka cipta.

Salama, Jestri Ostri. 2018. "Penerapan Model Pembelajaran Kooperatif Tipe Numbered Head Together Dalam Meningkatkan Hasil Belajar Siswa Kelas VIII G Pada Mata Pelajaran IPS Terpadu Di SMP Negeri 4 Tondano." Jurnal Pendidikan Ekonomi, Volume 3, Nomor 3.

Sanjaya, I Putu Eka. 2013. Penerapan Model Pembelajaran Kooperatif Tipe NHT Untuk Meningkatkan Motivasi Dan Hasil Belajar Teknik Dasar Passing Bola Basket Pada Siswa Kelas X5 SMA Negeri 1 Negara Tahun Pelajaran 2012/2013. Skripsi (tidak diterbitkan). Jurusan Penjaskesrek, Undiksha Singaraja.

Sucidamayanti, Ni Putu Wiwin. 2011.Penerapan Model Pembelajaran Kooperatif Tipe Numbered Heads Together (NHT) untuk Meningkatkan Hasil Belajar IPS Siswa Kelas IV Semester II SD No 1 Beratan Kecamatan Buleleng Kabupaten Buleleng Tahun Pelajaran 2010/2011. Skripsi (tidak diterbitkan). Jurusan Pendidikan Guru Sekolah Dasar, FIP,Undiksha.

Tirtawati, Ni Wayan. 2013. Penerapan Model Pembelajaran Kooperatif Tipe NHT Untuk Meningkatkan Motivasi Dan Hasil Belajar Teknik Dasar Berguling (Roll) Senam Lantai Pada Siswa Kelas XI IPA 3 SMA Negeri 2 Bangli Tahun Pelajaran 2012/2013. Skripsi (tidak diterbitkan). Jurusan Penjaskesrek, Undiksha Singaraja.

Teguh Karya,Tut Ria, dkk. 2016. PENERAPAN MODEL PEMBELAJARAN KOOPERATIF TIPE NUMBERED HEAD TOGETHER UNTUK MENINGKATKAN AKTIVITAS DAN HASIL BELAJAR TEKNIK DASAR PASSING BOLA BASKET. Jurnal Pendidikam Jasmani, Olahraga dan Kesehatan Undiksha, Volume 5, Nomor 2.

Yuliana, L. R., Susanti, R., \& Bintari, S. H. (2018). Penerapan Model Pembelajaran Numbered Heads Together (NHT) terhadap Hasil Belajar Siswa pada Materi Sistem Ekskresi. Journal of Biology Education, 7(2), 209-215. 